\title{
Effect of Post-Treatment Conditions on the Inactivation of MS2 Bacteriophage as Indicator for Pathogenic Viruses after the Composting Process
}

\author{
Hamidatu S. Darimani ${ }^{*}$, Ryusei Ito², Naoyuki Funamizu², Amadou H. Maiga3 \\ ${ }^{1}$ School of Engineering, Wa Polytechnic, Upper West Region, Ghana \\ ${ }^{2}$ Faculty of Engineering, Hokkaido University, Sapporo, Japan \\ ${ }^{3}$ Water and Climate Centre, International Institute for water and Environmental Engineering (2iE), \\ Ouagadougou, Burkina Faso \\ Email: ^hamidnid2012@gmail.com
}

How to cite this paper: Darimani, H.S., Ito, R., Funamizu, N. and Maiga, A.H. (2018) Effect of Post-Treatment Conditions on the Inactivation of MS2 Bacteriophage as Indicator for Pathogenic Viruses after the Composting Process. Journal of Agricultural Chemistry and Environment, 7, 73-80.

https://doi.org/10.4236/jacen.2018.72007

Received: January 22, 2018

Accepted: May 11, 2018

Published: May 14, 2018

Copyright $\odot 2018$ by authors and Scientific Research Publishing Inc. This work is licensed under the Creative Commons Attribution International License (CC BY 4.0).

http://creativecommons.org/licenses/by/4.0/

\begin{abstract}
A rural model composting toilet system still had some pathogens in the compost after months of operation and hence requires a post-treatment. The aim of the study was to sanitize compost withdrawn from the composting toilet by setting post-treatment conditions. The kinetics inactivation of MS2 bacteriophage, selected as indicator for pathogenic viruses were determined during post-treatment at different temperatures $\left(30^{\circ} \mathrm{C}, 40^{\circ} \mathrm{C}\right.$ and $\left.50^{\circ} \mathrm{C}\right)$ with varying moisture contents $(50 \%, 60 \%$ and $70 \%)$. As a result, the inactivation rates during the post-treatment were $0.093-0.020 \mathrm{~h}^{-1}, 0.025-0.088 \mathrm{~h}^{1}, 0.447-$ $0.100 \mathrm{~h}^{-1}$ at $30^{\circ} \mathrm{C}, 40^{\circ} \mathrm{C}$ and $50^{\circ} \mathrm{C}$ respectively. The inactivation rate coefficient $(k)$ values of MS2 bacteriophage depended on higher temperature but not on moisture content.
\end{abstract}

\section{Keywords}

Composting Toilet, MS2 Bacteriophage, Temperature, Moisture Content, Post-Treatment

\section{Introduction}

A composting toilet, which was modified from the commercial type available in Japan, has been installed in rural parts of Burkina Faso in an attempt to alleviate sanitation problems and to improve food security in the area. The function of the composting toilet system is to enhance the efficient organic decomposition 
of faeces with little odour [1]. This is a sustainable sanitation system to protect human health and the environment while reducing the use of water and recycling nutrients [2]. Farming is the main occupation of the people in the area [3]. A family with six people earned 132 Euro in Zinaire from the reuse of compost, urine and grey water in their sanitary gardens [4]. The people are encouraged to use the composting toilet to make compost for their gardens. The inactivation rate of pathogenic viruses in the compost needs to be assessed before reuse on the farmlands.

There is no information available for the treatment of compost in Burkina Faso using heat inactivation of pathogenic viruses. In spite of the importance of viruses as a pathogen causing a wide range of infectious diarrhoea, nausea, vomiting, hepatitis, and meningitis throughout the years in developing countries, attention has not been paid to inactivation of viruses in compost using an affordable sanitisation method such as the solar energy. E. coli has been used for the verification and monitoring of treated excreta [5]. However, E. coli cannot be used to monitor viruses that have a strong tolerance [1]. Certain coliphage are considered an appropriate indicator than coliform bacteria to monitor viruses in a water environment [6]. Enteric bacteriophages specifically, $\mathrm{F}^{+}$RNA bacteriophage infecting Escherichia coli, have been proposed as more reliable indicators of human viral pathogens [7] because they are similar to human enteric viruses in their physical structure, composition, and morphology, survivability in the environment, and persistence in treatment processes [7] [8] [9]. $\mathrm{F}^{+}$RNA coliphages can also be detected and quantified by simple, inexpensive, rapid, and reliable methods [7] [10]. They are abundant in domestic wastewater, raw sewage sludge, and polluted waters [7] and originate almost exclusively from the faeces of humans [11]. The study specifically, studied the thermal inactivation of MS2 in the laboratory. The laboratory test is important to simulate the conditions affecting MS2 under thermal heat. The main aim of the study was to sanitise compost withdrawn from the rural model of composting toilet by setting post-treatment conditions. The specific objectives of this research were 1) to determine the kinetic parameters of inactivation of MS2 bacteriophage during a post-treatment of compost; and 2) to evaluate the effect of temperature and moisture content on the inactivation rate coefficients $\left(k \cdot h^{-1}\right)$.

\section{Material and Methods}

\subsection{Measuring MS2 Bacteriophage}

MS2 bacteriophage was obtained from the National Biological Resource Centre (NBRC), National Institute of Technology and Evaluation, Japan. Bacteriophage MS2 belongs to the family levividae and it was used as the reference bacteriophage for F-specific RNA bacteriophage [12] used as host bacteria for MS2 bacteriophage. LB (Luria Bertani) broth was used as a growth medium for coliphage and E. coli strain. E. coli was incubated in a shaking water bath at $37^{\circ} \mathrm{C}$ for 4 hours. In order to measure the concentration of microorganism in the compost, 
microorganism needs to be extracted into a solution [1]. A 4\% (w/v) phosphate buffer solution was used as an extraction solution. The phosphate buffer was prepared by dissolving $42.5 \mathrm{~g}$ of $\mathrm{KH}_{2} \mathrm{PO}_{4}$ to $500 \mathrm{ml}$ of pure water. The $\mathrm{pH}$ was adjusted to 7.2 with $4(\mathrm{w} / \mathrm{v})$ of $\mathrm{NaOH}$, then autoclaved. The compost at $4 \%(\mathrm{w} / \mathrm{v})$ was then agitated for 3 minutes to extract MS2 bacteriophage in the Phosphate buffer solution. LB broth was used to dilute the extracted solution to a suitable concentration for measuring the organism. The LB broth was prepared by dissolving $10 \mathrm{~g}$ of polypetone, $5 \mathrm{~g}$ of Bacto Yeast Extract, $1.5 \mathrm{~g}$ of glucose, $5 \mathrm{~g}$ of $\mathrm{NaCl}, 0.2 \mathrm{~g}$ of $\mathrm{MgSO}_{4} \cdot 7 \mathrm{H}_{2} \mathrm{O}$ and $0.5 \mathrm{~g} \mathrm{MnSO}_{4} \cdot 5 \mathrm{H}_{2} \mathrm{O}$ in $1000 \mathrm{ml}$ of distilled water, then autoclaved. MS2 was enumerated by plaque assay with $E$. coli NBRC 13,965 using a double agar overlay technique and using LB agar [1] [12]. Plaques were observed and enumerated following 18 to 24 hours of incubation at $37^{\circ} \mathrm{C} \pm 2^{\circ} \mathrm{C}$. The results were converted to the plaque weight of compost.

\subsection{Compost Preparation and Inoculation}

Twenty grammes $(20 \mathrm{~g})$ of compost was weighed into $250 \mathrm{ml}$ sterilised bottle. The compost was prepared by loading $500 \mathrm{~g}$-wet of pig manure to $3 \mathrm{~kg}$ of rice husk in a composter with a mixing mechanism for 30 days. After composting, it was kept in the composter for 1 week to reduce moisture. The moisture content measured before the experiment was $27 \%$. Ultra-pure water was added to adjust moisture content of the compost. The combinations of temperature and moisture content of the experiments are summarised in Table 1. To study the combined effect of temperature, moisture content and contact time, temperatures were set to $30^{\circ} \mathrm{C}, 40^{\circ} \mathrm{C}$ and $50^{\circ} \mathrm{C}$. In Burkina Faso, the average temperature is approximately $30^{\circ} \mathrm{C}$. The temperature of the compost can be increased when exposed to solar thermal heat. During a proper operation of the composting toilet, the moisture content is kept around 50\% - 60\% [13]. Therefore, moisture contents were set to 50\% (normal condition), 60\% and 70\% (anaerobic conditions). Here, the moisture content is defined by the following equation below:

Table 1. Experimental conditions for thermal treatment for MS2.

\begin{tabular}{ccc}
\hline No. of sample & Temperature ${ }^{\circ} \mathrm{C}$ & Moisture content \\
\hline 1 & 30 & $50 \%$ \\
2 & & $60 \%$ \\
3 & & $70 \%$ \\
4 & 40 & $50 \%$ \\
5 & & $60 \%$ \\
6 & & $70 \%$ \\
7 & 50 & $50 \%$ \\
8 & & $60 \%$ \\
9 & & $70 \%$ \\
\hline
\end{tabular}




$$
\text { Moisture content, } M C=\frac{W_{w e t}-W_{d r y}}{W_{d r y}} \times 100
$$

where, $W_{\text {wet }}$ and $W_{d r y}$ are wet and dry weights of compost sample, g. The bottles were inoculated with MS2 bacteriophage which contains $3.2 \times 105 \mathrm{PFU} / \mathrm{g}$-dry compost. The compost was agitated for 1 minute to ensure that MS2 bacteriophage was uniformly mixed. The bottles were tightly closed to control any change in moisture content during the thermal treatment. The samples were then immediately placed into the incubator to keep temperature constant. Moisture content did not change throughout the experiment for all thermal treatments. The total treatment time was 8 hours. One gramme $(1 \mathrm{~g})$ of the compost sample was taken at $2 \mathrm{~h}$ interval for all experimental conditions.

\subsection{Data Analyses}

To determine virus inactivation rates, the number of virus per gram (dry weight) of the compost were transformed into log10 PFU/gram (dry weight) of compost. Concentration versus time data obtained from the inactivation experiments were fitted to a first order kinetic model. This was done for thermal treatment of MS2 bacteriophage. Nakagawa et al. [2], indicated that inactivation of microorganisms follows a first order reaction and it is expressed as:

$$
\ln k=C / C_{o}=-k t
$$

where, $C$ is concentration of microorganism in compost sample in dry basis at time, $t$ (PFU/g-dry solid), $C_{o}$ is initial concentration of microorganisms in compost sample in dry basis (PFU/g-dry solid), $\mathrm{k}$ is inactivation rate coefficient $\left(\mathrm{h}^{-1}\right)$, and $t$ is reaction time $(h)$. After the estimation of inactivation rate coefficients $\left(\mathrm{k} \cdot \mathrm{h}^{-1}\right)$, the effect of temperature was evaluated with Arrhenius equation described as follows;

$$
k=A \exp \left(-\frac{E_{a}}{R T}\right)
$$

where, $A$ is pre-exponential factor, $E_{a}$ is activation energy $(\mathrm{J} / \mathrm{mol}), R$ is universal gas constant $(\mathrm{J} / \mathrm{mol} / \mathrm{K}), T$ is temperature $(K)$. ANOVA was done to determine the significant effect $(p \leq 0.05)$ due to increasing temperature and moisture on the inactivation coefficient rate values of MS2. The analysis was performed with R (open source coding software) using the packages "stats" for the ANOVA and Shapiro test.

\section{Results and Discussion}

\subsection{MS2 Bacteriophage Inactivation in Compost}

The concentration of MS2 bacteriophage decreased as the temperature increased, moisture content (MC) decreased and the length of time increased. The characteristics of $\mathrm{MS} 2$ at $30^{\circ} \mathrm{C}$ for the conditions of moisture content $(50 \%, 60 \%$, and $70 \%)$ is shown in Figure 1(a). At this temperature the inactivation rate coefficients, $k \cdot h^{-1}$, values were almost zero. This indicates no reduction in the 


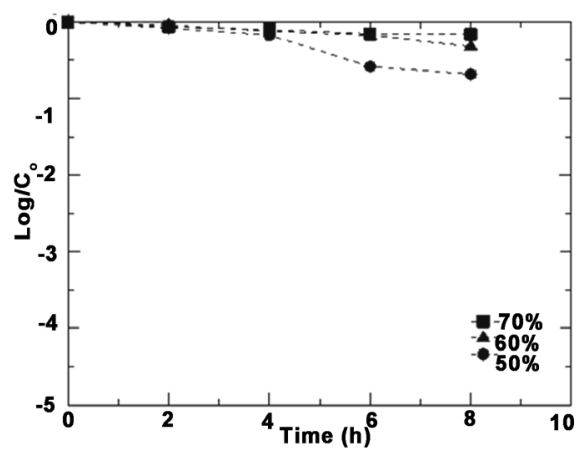

(a)

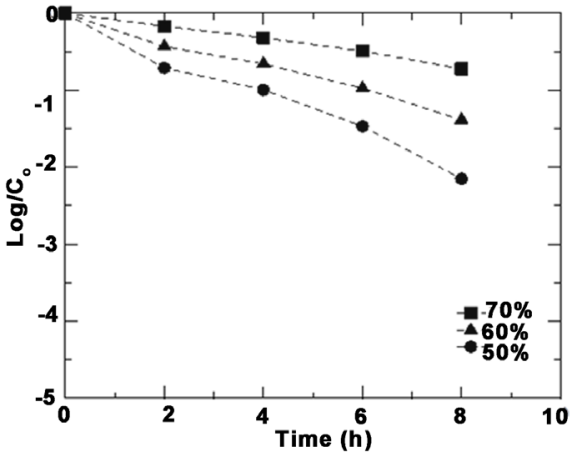

(b)

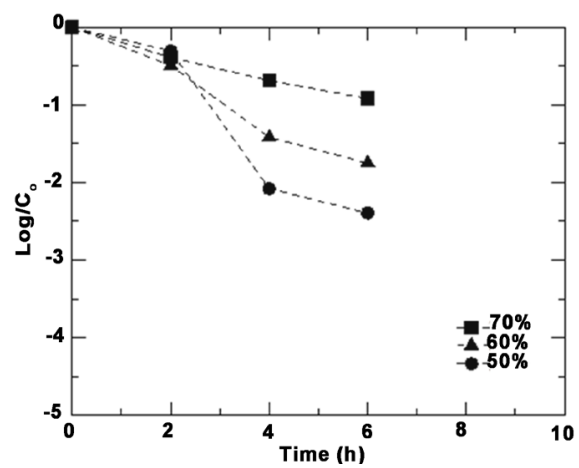

(c)

Figure 1. Inactivation of MS2 bacteriophage at $30^{\circ} \mathrm{C}(\mathrm{a}), 40^{\circ} \mathrm{C}(\mathrm{b})$ and $50^{\circ} \mathrm{C}(\mathrm{c})$.

concentration of MS2 at $30^{\circ} \mathrm{C}$ within the 8 hour treatment period. Figure 1 (b) shows the change in concentration of MS2 at $40^{\circ} \mathrm{C}$ with moisture content of $50 \%, 60 \%$ and $70 \%$. The inactivation rate coefficients, $k \cdot \mathrm{h}^{-1}$, values were 0.252 , $0.165,0.088$ for the respective moisture contents. At $40^{\circ} \mathrm{C}$, the log unit reduction recorded for $50 \%$ was $2 \log$ units, $60 \%$ moisture was $1 \log$ and $70 \%$ recorded $<1$ $\log$ unit in 8 hours. Figure 1(c) shows the change in concentration of MS2 at $50^{\circ} \mathrm{C}$. The total length of time for treatment was 8 hours at $50^{\circ} \mathrm{C}$; the point at the $8^{\text {th }}$ hour was not shown because there was no count. Presenting 0 count on a log plot was impossible and hence the omission. The inactivation rate coefficients, $k$, values at $50^{\circ} \mathrm{C}$ at $50 \%, 60 \%, 70 \%$ moisture content were $0.447,0.308$ and 0.100 respectively. Treatment at $50^{\circ} \mathrm{C}$ with moisture $50 \%, 60 \%, 70 \%$ recorded $>3 \log$ units, $>1 \log$ unit and $<1 \log$ units reductions in 8 hours. Table 2 shows the summarised inactivation rate coefficients, $\left(k \cdot \mathrm{h}^{-1}\right)$ data during the post-treatment of MS2 bacteriophage with varying temperature and moisture contents. The coefficient of determination, $R^{2}$, for the linear fit of the inactivation rate of the MS2 was in the range of $0.8-0.9$.

\subsection{Effect of Temperature and Moisture on MS2 Inactivation}

Thermal treatment is a method employed by many sludge generators to inactivate pathogens. The proposed thermal treatment is inexpensive and generate a product beneficial and acceptable for agricultural use. The evaluation of a cost effective solution for sufficient inactivation of pathogen provides valuable 
Table 2. Summary of inactivation rate coefficients, $k \cdot h^{-1}$ MS2 bacteriophage.

\begin{tabular}{cccc}
\hline & \multicolumn{3}{c}{ Moisture content, MC (\%) } \\
\cline { 2 - 4 } Temp. ${ }^{\circ} \mathrm{C}$ & $k, \mathrm{~h}^{-1}(50 \%)$ & $k, \mathrm{~h}^{-1}(60 \%)$ & 0.020 \\
\hline 30 & 0.093 & 0.038 & 0.088 \\
40 & 0.252 & 0.165 & 0.100 \\
\hline
\end{tabular}

information for implementation of the technology. The study focused on the inactivation rate for MS2 bacteriophage in compost as affected by temperature and moisture content in a laboratory experiment. Enteric viruses are of importance with regards to land application of compost due to potential of run-off resulting in surface contamination and potential movement of viruses in the soil column into underground aquifers. Such movement is enhanced during rainfall events where the cation particulates are reduced and vary with soil composition. Inactivation rate of MS2 in a possible additional treatment after the composting such as drying up with air (Low moisture content) and heating by solar energy (high temperature) was tried with laboratory test. High temperature has been regarded as one of the most important critical factors governing the inactivation of MS2 bacteriophage [2]. It was found that, inactivation rates increased with increasing temperature from $40^{\circ} \mathrm{C}$ to $50^{\circ} \mathrm{C}$ (Figure $1(\mathrm{~b})$ and Figure $1(\mathrm{c})$ ) and this was statistically significant $(p \leq 0.05)$ (Table 3$)$. These findings conformed to the studies of Kazama et al. [1], who indicated that, inactivation of MS2 are strongly dependent on temperature.

Results showed that, there was no change in concentration of MS2 after eight (8) hours treatment period at $30^{\circ} \mathrm{C}$ which indicates that, lower temperatures facilitate the survival of MS2. Range of temperature from $40^{\circ} \mathrm{C}-50^{\circ} \mathrm{C}$ and above are capable of inactivating MS2 as shown in these results. However, rates will obviously vary with varying temperature. Inactivation rate coefficients, $k, \mathrm{~h}^{-1}$, varied under different post-treatment conditions. During the treatment, relevant data were gathered for the inactivation rate coefficients. Arrhenius plots for MS2 inactivation is shown in Figure 2. The solid lines shows the correlation for the effect of temperature on MS2 at different moisture content, 50\%, 60\% and 70\%. The broken lines show the actual pattern of effect of temperature. There was a strong correlation between temperature $30^{\circ} \mathrm{C}, 40^{\circ} \mathrm{C}$ and $50^{\circ} \mathrm{C}$ for all moisture levels. This indicates that, there is a greater effect of temperature for the various treatments.

Lower moisture conditions increased the inactivation rate coefficients, $k, \mathrm{~h}^{-1}$ values in all our experiments. However, the difference in the $k$ values was not statistically significant. These results are clearly shown in Figure 2. Conditions with lower moisture 50\% recorded higher inactivation rates indicating that compost with moisture content below $50 \%$ can enhance the inactivation process during post-treatment. Inactivation rates are higher with increasing temperature and lower moisture content. Kazama et al. [1], showed that inactivation rate 


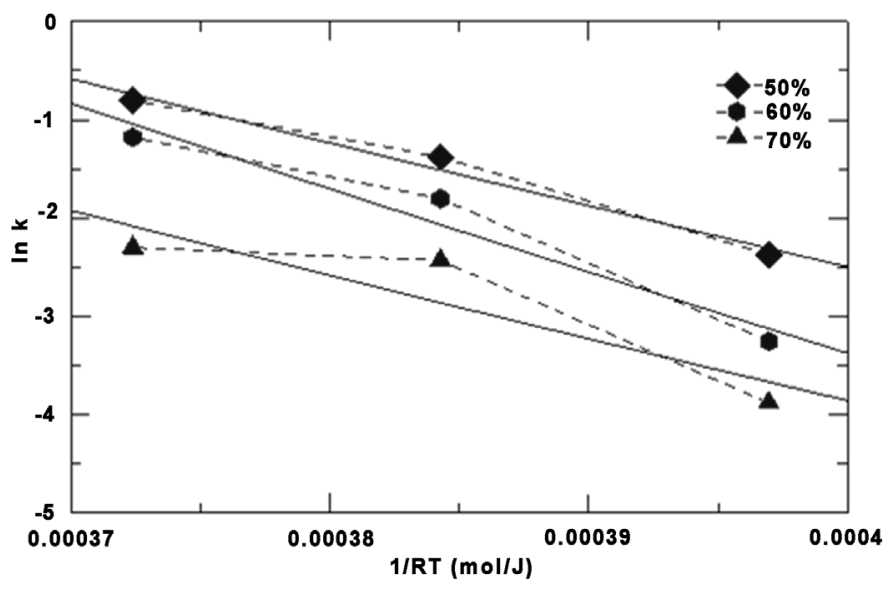

Figure 2. Effect of temperature on MS2 inactivation with varying moisture content. $\mathrm{R}^{2}$ values for the trend of MC $50 \%, 60 \%$ and $70 \%$ are $0.98,0.95$ and 0.82 respectively.

Table 3. Analysis of Variance for MS2 bacteriophage

\begin{tabular}{cccccc}
\hline Source of Variation & Sum sq. & DOF & Mean Sq. & $F$ & $p$-values \\
\hline Anova Temp. & 0.082604 & 2 & 0.041302 & 8.0645 & 0.03949 \\
Anova Moisture & 0.056870 & 2 & 0.028435 & 5.5521 & 0.07013 \\
Residuals & 0.020486 & 4 & 0.005121 & & \\
\hline
\end{tabular}

coefficients, $\left(\mathrm{k} \cdot \mathrm{h}^{-1}\right)$ at $50^{\circ} \mathrm{C} 40 \%$ moisture was 0.40 while the study reported 0.447 at $50^{\circ} \mathrm{C}, 50 \% \mathrm{MC}$ (Table 2). The study observed that the rate of coliphage decreased more rapidly at high temperature because the inactivation rate coefficients, at $50^{\circ} \mathrm{C}$ were higher than at $30^{\circ} \mathrm{C}$. This study reported the same trend. The most performing post-treatment condition was $50^{\circ} \mathrm{C} 50 \% \mathrm{MC}$ which recorded a $>3 \log$ units reduction in 8 hours. The experimental data were important to allow simulation of inactivation of pathogens under solar thermal heat.

\section{Conclusion}

A composting toilet system is supposed to inactivate pathogens in compost before reuse as fertilizer. There was insufficient heat in the composting process in the rural model of composting toilet. A post-treatment of the compost was necessary to increase the health and safety of farmers. Inactivation of MS2 bacteriophage (viral pathogens) in a possible additional post-treatment after the composting process by dying-up with air (lower moisture) and temperature (solar thermal heat) was investigated in the laboratory test. As a result, the inactivation rate coefficient $(k)$ values of MS2 bacteriophage depended on higher temperature but not on moisture content. The inactivation rates during the post-treatment were $0.093-0.020 \mathrm{~h}^{-1}, 0.025-0.088 \mathrm{~h}^{1}, 0.447-0.100 \mathrm{~h}^{-1}$ at $30^{\circ} \mathrm{C}$, $40^{\circ} \mathrm{C}$ and $50^{\circ} \mathrm{C}$ respectively.

\section{Acknowledgements}

This study was carried out with the grand project of Science and Technology 
Research Partnership for Sustainable Development (SATREPS) supported by JST (Japan Science and Technology agency) and JICA (Japan International Cooperation Agency).

\section{References}

[1] Kazama, S., Tameike, N., Nakagawa, N. and Otaki, M. (2011) A Fate Model of Pathogenic Viruses in a Composting Toilet Based on Coliphage Inactivation. Journal of Environmental Sciences, 23, 1194-1198. https://doi.org/10.1016/S1001-0742(10)60490-1

[2] Nakagawa, N., Oe, H., Otaki, M. and Ishizaki, K. (2006) Application of Microbial Risk Assessment on a Residentially-Operated Bio-Toilet. Journal of Water Health, 4, 479-486.

[3] Ito, R., Ushijima, K., Hijikata, N. and Funamizu N. (2012) Survey of Sanitation Conditions in Burkina Faso for Design of Toilet. Proceedings of 4th Dry Toilet Conference, Tampere, 22-24 August 2012.

[4] Hijikata, N., Sangare, D., Sou/Dakoure, M., Toure, I., Ushijima, K., Ito, R. and Funamizu, N. (2014) Evaluation of Vegetable Yields for Income Estimation Using Human Urine and Compost Originated from On-Site Resource Oriented Sanitation System, a Case of Burkina Faso. Proceedings of IWA Specialist Conference, Nepal, 26-30 October 2014.

[5] WHO (2006) Guidelines for the Safe Use of Wastewater, Excreta and Greywater. World Health Organisation, Geneva.

[6] Moce-Llivina, L., Muniesa, M., Pimenta-Vale, H., Lucena, F. and Jofre, J. (2003) Survival of Bacterial Indicator Species and Bacteriophages after Thermal Treatment of Sludge and Sewage. Applied and Environmental Microbiology, 69, 1452-1456. https://doi.org/10.1128/AEM.69.3.1452-1456.2003

[7] Nappier, S.P., Aitken, M.D. and Sobsey, M.D. (2006) Male-Specific Coliphage as Indicators of Thermal Inactivation of Pathogens in Biosolids. Applied and Environmental Microbiology, 72, 2471-2475. https://doi.org/10.1128/AEM.72.4.2471-2475.2006

[8] Funderburg, S.W., and Sorber, C.A. (1985) Coliphage as Indicators of Enteric Viruses Inactivated Sludge. Water Research, 19, 547-555. https://doi.org/10.1016/0043-1354(85)90059-4

[9] Havelaar, A.H. (1987) Bacteriophages as Model Organisms in Water Treatment. Microbiological Sciences, 4, 362-364.

[10] Havelaar, A.H., van Olphen, M. and Drost, Y.C. (1993) F-Specific RNA Bacteriophages Are Adequate Model Organisms for Enteric Viruses in Freshwater. Applied and Environmental Microbiology, 59, 2956-2962.

[11] Sobsey, M.D., Battigelli, D., Handzel, T. and Schwab, K. (1995) Male-Specific Coliphages as Indicators of Viral Contamination of DRINKING Water. Proceedings of the 1994 Water Quality Technology Conference, American Water Works Association, Denver, 7-11 November 1995, 1847-1862.

[12] Hensen, J.J., Warden P.S. and Margolin, A.B. (2007) Inactivation of Adenovirus Type 5, Rotavirus WA and Male Specific Coliphage (MS2) in Biosolids by Lime Stabilization. International Journal of Environmental Research and Public Health, 4, 61-67. https://doi.org/10.3390/ijerph2007010010

[13] Lopez Zavala, M.A., Funamizu, N. and Takakuwa, T. (2004) Modeling of Aerobic Biodegradation of Using Sawdust as a Matrix. Water Research, 38, 1327-1333. https://doi.org/10.1016/j.watres.2003.10.028 